\author{
BAJZÁT TüNDE \\ Miskolci Egyetem \\ bajzat.tunde@uni-miskolc.hu
}

\title{
NYELVTANÁRI MOTIVÁCIÓS STRATÉGIÁK GYAKORISÁGI HASZNÁLATA A BORSOD-ABAÚJ-ZEMPLÉN MEGYEI RÉGIÓ NÉHÁNY KÖZÉPISKOLÁJÁBAN
}

\section{Bevezetés}

A motiváció kulcsfontosságú szerepet játszik a nyelvtanulásban és a nyelvoktatásban egyaránt. A „[...] motiváció több nyelvtanulási stratégia használatához vezet, amely az eredményesség révén növeli az önbizalmat, az önbizalom pedig tovább erősíti a motivációt" (Bárdos 2000: 240).

A nyelvtanulás folyamatában a motivált tanár és a tanulóit motiválni tudó tanár is kulcsfontosságú szerepet játszik. A motivált tanár elkötelezett munkája és diákjai iránt, lelkes, és ezt át is tudja adni tanulóinak nemcsak szavaival, de viselkedésével is. A motiváció segít ösztönözni, irányítani és hosszú ideig fenntartani a tanuláshoz való pozitív hozzáállást. Nemcsak a célok elérését növeli, hanem ösztönzi a kreativitást, a kíváncsiságot és az igényt is a további tanulásra. A tanár különbözőféleképpen gyakorol hatást diákjai motivációjára a mindennapi órai munka során. A motivált tanár befolyásolja: a tanulók nézeteit saját képességeikről, hozzáállásukat bizonyos témákhoz, rövid és hosszú távú terveiket, a sikereikhez és kudarcaikhoz való hozzáállásukat és nyelvtanulásuk okait.

Ennek jegyében született tanulmányom, melynek célja, hogy megvizsgálja az angol és német nyelvet tanító tanárok különböző motivációs makro- és mikrostratégiáinak gyakoriságát a nyelvórán 16 középiskolában, Borsod-Abaúj-Zemplén megyében. A tanulmány első része a kutatás elméleti hátterét mutatja be. A második rész a 2018 őszén készült empirikus kutatás részeredményeit ismerteti.

\section{A kutatás elméleti háttere}

A nyelvtanulás folyamatában a tanuló lelkesedése, elkötelezettsége és kitartása kulcsfontosságú szerepet tölt be a nyelvtanulás sikerében vagy annak kudarcában. Az esetek többségében a motivált diák használható idegennyelv-tudásra tehet szert, tekintet nélkül nyelvérzékére és kognitív képességére. Motiváció hiányában viszont a legtehetségesebb tanuló sem valószínű, hogy elegendő ideig kitart majd, hogy használható nyelvtudást sajátítson el. Ebből következően a tanár feladata az, hogy motivációs stratégiák használatával elősegítse a célorientált viselkedést. A motivációs stratégiák olyan motivációs 
hatások, amelyeket a tanár tudatosan alkalmaz azért, hogy módszeres és tartós pozitív hatást érjen el. A motivációs stratégiák négy nagy csoportba oszthatók, amelyek a következők: az alap motivációs feltételek megteremtése, a kezdeti motiváció előidézése, a motiváció fenntartása és megőrzése, és a pozitív önértékelés bátorítása. A csoportok különböző makrostratégiákat (összesen 35) tartalmaznak, ezek pedig további, a stratégiához kapcsolódó mikrostratégiákat (Dörnyei 2001).

Dörnyei Zoltán és Csizér Kata Magyarországon angol nyelvtanárok körében végzett kutatást a motivációs stratégiák használatának gyakoriságáról. A vizsgálat kimutatta, hogy a leggyakrabban alkalmazott makrostratégiák a következők voltak: megfelelő tanári viselkedés, kellemes osztálytermi légkör megteremtése és a feladatok megfelelö elmondása/bemutatása. A kevésbé alkalmazott stratégiák az alábbiak voltak: a tanulói önbizalom növelése, a feladatok ösztönzővé tétele és a tanulói autonómia növelése. A legritkábban alkalmazott makrostratégiák pedig a tanulói teljesítmény elismerése, a célorientáltság növelése és a célnyelvvel kapcsolatos értékek megismertetése voltak (Dörnyei-Csizér 1998).

Hsing-Fu Cheng és Dörnyei Zoltán tajvani angol nyelvtanárok körében folytatott hasonló motivációs kutatást 10 makrostratégia és azokhoz kapcsolódó mikrostratégiák körében. Az eredmények rávilágítottak arra, hogy a vizsgálatban részt vevő nyelvtanárok által leggyakrabban alkalmazott makrostratégia a megfelelő tanári viselkedés volt, amelyet a tanulói teljesítmény elismerése, a tanulói önbizalom növelése és a kellemes osztálytermi légkör megteremtése követett. A megkérdezettek ritkábban végezték az alábbi makrostratégiákat: a feladatok megfelelő elmondása/bemutatása, a célorientáltság növelése és a feladatok ösztönzővé tétele. A tajvani válaszadók által legritkábban használt makrostratégiák: a célnyelvvel kapcsolatos értékek megismertetése, a csoportkohézió növelése és végezetül a tanulói autonómia növelése volt (Cheng-Dörnyei 2007).

\section{Anyag és módszer}

\subsection{A kutatás célja és módszere}

A tanulmány következtetései egy empirikus felmérés eredményei alapján fogalmazhatók meg. A 2018 őszén elvégzett vizsgálat célja az volt, hogy megismerje az angol és német nyelvet tanító tanárok különböző motivációs stratégiáinak gyakoriságát a nyelvórán.

Az adatgyűjtés módszerei közül a kérdőíves adatfelvételt választottam. A kérdőíves adatfelvételt az egységesség, a könnyebb feldolgozhatóság indokolta. A választás másik oka az, hogy a jelen kutatás felderítő kutatás, és a kérdőíves adatfelvétel alkalmas ilyen célra. Főként olyan kutatásokban használják, amelyekben az elemzési egység az egyes ember, illetve az adatközlők egyes emberek. A standardizált kérdőívek továbbá minden válaszadóról ugyanolyan formában nyújtanak adatokat (Babbie 2001). 
A magyar nyelvü kérdőív zárt és nyitott kérdéseket, valamint Likert-skálákat tartalmazott. A zárt kérdések esetén a lehetséges válaszokat a kutató határozza meg. A zárt kérdések egységesebb mérést követelnek meg, ezért megbízhatóságuk is nagyobb, és a válaszok is könnyen összegezhetők, elemezhetők. Ezzel szemben a nyitott kérdésekre a válaszadók tetszés szerint válaszolhatnak, leírhatják gondolataikat és véleményüket, ezért a kapott adatok nem kiszámíthatók, ugyanakkor mélyrehatók (Mackey-Gass 2005).

A magyar nyelvủ kérdőív zárt és nyitott kérdései rákérdeztek a nyelvtanárok általános adataira és munkatapasztalataira. Az ötfokú Likert-skála (mindig, gyakran, néha, ritkán, soha) 48 állítást tartalmazott a Hsing-Fu Cheng és Dörnyei Zoltán által elvégzett kutatások 10 makrostratégiája és az azokhoz kapcsolódó 13 mikrostratégia alapján. A tíz makrostratégia a következő volt: megfelelő tanári viselkedés, kellemes osztálytermi légkör teremtése, a tanulói önbizalom növelése, a célorientáltság növelése, a tanulói teljesítmény elismerése, a feladatok megfelelő elmondása/bemutatása, a feladatok ösztönzővé tétele, a célnyelvvel kapcsolatos értékek megismertetése, a csoportkohézió növelése, és a tanulói autonómia növelése. Ezek közül a jelen tanulmány három makrostratégia (a tanulói önbizalom növelése, a célorientáltság növelése, és a tanulói teljesítmény elismerése) eredményeit mutatja be.

A kérdőíves adatgyüjtés során az önkitöltős módszert alkalmaztam, a kérdőíveket a válaszadók papír alapon kapták meg és töltötték ki. A kérdőív kitöltése önkéntes volt, a megkérdezettek megőrizték anonimitásukat.

\subsection{A kutatási minta}

A kutatásban 16 Borsod-Abaúj-Zemplén megyében található középiskola angol és német szakos nyelvtanárai vettek részt. A 16 iskola közel fele (7 iskola, 44\%) Miskolcon található, a többi oktatási intézmény (9 iskola, 56\%) pedig a megye nagyvárosaiban: Edelényben, Kazincbarcikán, Putnokon, Szerencsen, Szikszón, Tiszaújvárosban és Ózdon. Az intézmények egy része (6 iskola, 37,5\%) szakközépiskola (egészségügyi, informatikai, művészeti, kereskedelmi és idegenforgalmi, mezőgazdasági, villamosipari), 5 iskola (31\%) általános és középiskola is egyben, 3 iskola (19\%) gimnázium, 2 iskola $(12,5 \%)$ gimnázium és szakközépiskola, 6 iskola $(37,5 \%)$ pedig kollégiummal is rendelkezik. Az intézmények nagy része (12 iskola, 75\%) állami fenntartású, 3 iskolát (19\%) a katolikus egyház működtet, egy iskolát (6\%) pedig a református egyház.

Az 1. táblázat a vizsgálatban részt vett 31 nyelvtanár általános adatait és képzettségét tartalmazza. A táblázatban látható, hogy a megkérdezettek nagy része nő (29 fö, 94\%), és csak 2 férfi (6\%) válaszolt a kérdésekre. A kutatásban résztvevők átlagéletkora 43,97 év, akik közül csupán 2 fö (7\%) tartozik a legfiatalabb korosztályba (25-30 év között). A válaszadók harmada (10 fó, 32\%) 31 és 40 éves kor közötti, a megkérdezettek közel fele (13 fö, 42\%) 41 és 50 éves kor közötti, és az 50 év feletti korosztályt csupán néhányan (6 fö, 19\%) képviselik. Az életkori szórás értéke magas (8,53), mert nagy a korkülönbség a legfiatalabb (25 év) és a legidősebb (61 év) nyelvtanár között. A táblázatban 
az is megfigyelhető, hogy a válaszadók nagy része ( 25 fó, $81 \%$ ) egyetemi végzettséget szerzett, és a nyelvtanárok ötöde (6 fö, 19\%) rendelkezik föiskolai diplomával. Az adatközlők átlagos oktatási gyakorlat 19,97 év, néhányan (5 fö, 16\%) rendelkeznek 3 és 10 év közötti oktatói tapasztalattal. A válaszadók több mint egyharmada (12 fó, 39\%) 11 és 20 év közötti időt dolgozott tanári munkakörben, a megkérdezettek negyede (8fó, 26\%) 21 és 30 év közötti gyakorlattal rendelkezik, és az adatközlők ötöde (6 fö, 19\%) több mint 30 évet töltött el a tanári pályán. Az oktatási gyakorlat szórásának értéke magas $(9,93)$, az adatok szórtabbak, vagyis nagy eltérés mutatkozik a legkevésbé tapasztalt (3 éves oktatási gyakorlat) és a legtapasztaltabb (39 éves oktatási gyakorlat) tanár években számított oktatási gyakorlata között. A megkérdezettek harmada (11 fö, 35\%) tanult külföldön részképzésben egy szemesztert vagy vett részt 2-3 hetes módszertani továbbképzésen az oktatott nyelvnek megfelelő célországban (Angliában, az Egyesült Királyságban, Máltán vagy Németországban). Azonban a többségnek (20fo,, 65\%) nem volt ilyen lehetősége. A vizsgálatban részt vevő nyelvtanárok közel kétharmada (19fó, 61\%) angol nyelvet tanít, több mint egyharmaduk (12 fö, 39\%) pedig német nyelvtanárként dolgozik.

\begin{tabular}{|c|c|c|}
\hline & fó & százalékos érték \\
\hline \multirow[t]{2}{*}{ Nem } & nő: 29 fö & $94 \%$ \\
\hline & férfi: 2 fó & $6 \%$ \\
\hline \multirow[t]{5}{*}{ Életkor } & átlagéletkor: 43,97 év & - \\
\hline & 25-30 év között: 2 fö & $7 \%$ \\
\hline & 31-40 év között: 10 fö & $32 \%$ \\
\hline & 41-50 év között: 13 fö & $42 \%$ \\
\hline & 51-61 év között: 6 fö & $19 \%$ \\
\hline \multirow{2}{*}{$\begin{array}{l}\text { Legmagasabb iskolai } \\
\text { végzettség }\end{array}$} & BA (föiskola): 6 fö & $19 \%$ \\
\hline & MA (egyetem): 25 fö & $81 \%$ \\
\hline \multirow[t]{5}{*}{ Oktatási gyakorlat } & átlag: 19,97 év & - \\
\hline & 3-10 év között: 5 fö & $16 \%$ \\
\hline & 11-20 év között: 12 fö & $39 \%$ \\
\hline & 21-30 év között: 8 fö & $26 \%$ \\
\hline & 30 év felett: 6 fö & $19 \%$ \\
\hline \multirow[t]{2}{*}{ Külföldön tanult } & igen: 11 fö & $35 \%$ \\
\hline & nem: 20 fö & $65 \%$ \\
\hline
\end{tabular}

1. táblázat: A nyelvtanárok általános adatai és képzettsége $(\mathrm{n}=31)$ 


\section{A kutatás eredményei}

A következőkben a vizsgálat eredményeit írom le. Elsőként a nyelvtanárok önfejlesztését mutatom be. Ezt követően a különböző tanári makro- és mikrostratégiák gyakoriságát ismertetem, amelyet a tanulói önbizalom növelése, a célorientáltság növelése és a tanulói teljesítmény elismerése érdekében alkalmaznak.

\section{1. Önfejlesztés}

Az 1. ábra bemutatja, hogy a megkérdezett nyelvtanárok milyen gyakran szoktak tanártovábbképzésen részt venni. Az ábrán megfigyelhető, hogy a válaszadók közel fele (15 fo, 48\%) évente többször, több mint kétharmada (12 fö, 39\%) évente egyszer, 2 fó (6,5\%) kétévente és 2 fö (6,5\%) csupán ötévente vesz részt továbbképzésen. Az eredmények alapján elmondható, hogy a kutatásban részt vett nyelvtanárok nagy része (27 fö, 87\%) rendszeresen, évente továbbképzi magát, azaz jelentős a belső motivációja, igénye a továbbfejlődésre, és hogy naprakész ismeretekkel rendelkezzen, s így diákjai motivációját is erősíteni tudja.

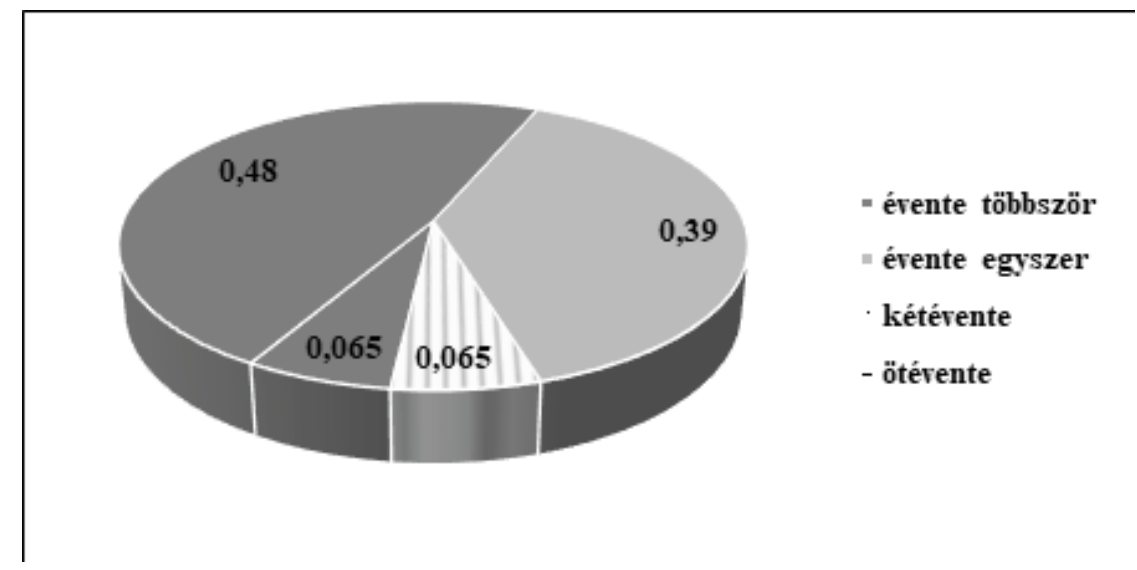

1. ábra: Milyen gyakran szokott tanártovábbképzésen részt venni? (n = 31)

\subsection{A tanulói önbizalom növelése}

A 2. táblázat a tanulói önbizalom növelésére használt mikrostratégiák gyakoriságát szemlélteti. A táblázatban látható, hogy az öt különböző mikrostratégia közül a válaszadók a tanulói önbizalom növelésére leggyakrabban pozitív visszajelzést adnak nyelvtanulóiknak idegen nyelvi fejlődésükről, a megkérdezettek háromnegyede (23 fő, 74\%) mindig megteszi ezt. Az is megfigyelhető, hogy a vizsgálatban részt vett nyelvtanárok fele mindig (16 fő, 51\%) egyértelműsíti tanulói számára, hogy a hatékony kommunikáció a legfontosabb a nyelvtanulás során, nem pedig a nyelvtani hibák miatti aggódás, és az adatközlők több mint egyharmada (12 fo, 39\%) gyakran alkalmazza ezt a mikrostratégiát. Továbbá 
a kutatás résztvevőinek fele (16 fö, 51\%) mindig érezteti diákjaival, hogy hisz bennük, és bátorítja őket arra, hogy ne adják fel a feladatot, próbálják meg újra és újra. A válaszadók több mint egyharmada (12 fó, 39\%) gyakran követi ezt a példát. A táblázat adatai arra is rávilágítanak, hogy a válaszadók csupán negyede (8fö, 26\%) készít mindig tanulói képességének megfelelő feladatokat a siker elérése érdekében, de a megkérdezettek több mint fele (19 fó, 61\%) gyakran alkalmazza ezt a mikrostratégiát. Az is látható, hogy a megkérdezett nyelvtanárok negyede (6 fö, 19\%) tanít rendszeresen különböző tanulási stratégiákat, és a válaszadók közel fele (14 fö, 45\%) gyakran él ezzel a lehetőséggel azért, hogy könnyebbé és hatékonyabbá tegye a nyelvtanulást.

\begin{tabular}{|c|c|c|c|c|c|c|}
\hline stratégiák & 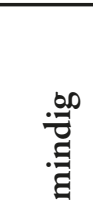 & 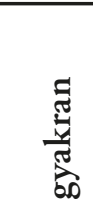 & $\underset{\mathscr{E}}{\overparen{\Xi}}$ & 胥 & $\frac{\pi}{0}$ & 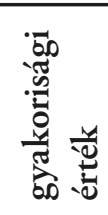 \\
\hline $\begin{array}{l}\text { Észreveszi a tanulók fejlődését és } \\
\text { pozitív visszajelzést ad erről. }\end{array}$ & $74 \%$ & $26 \%$ & $0 \%$ & $0 \%$ & $0 \%$ & 4,7 \\
\hline $\begin{array}{l}\text { Világossá teszi a tanulók számára, } \\
\text { hogy a nyelvtanulásban a legfon- } \\
\text { tosabb a hatékony kommunikálás } \\
\text { elérése és nem a nyelvtani hibák } \\
\text { miatti aggódás. }\end{array}$ & $51 \%$ & $39 \%$ & $10 \%$ & $0 \%$ & $0 \%$ & 4,4 \\
\hline $\begin{array}{l}\text { Bátorítja a tanulóit, hogy próbálják } \\
\text { tovább a feladatot, mert hisz abban, } \\
\text { hogy a tanulók képesek elvégezni } \\
\text { a feladatot. }\end{array}$ & $51 \%$ & $39 \%$ & $3 \%$ & $7 \%$ & $0 \%$ & 4,4 \\
\hline $\begin{array}{l}\text { Tanulói képességeinek megfelelő } \\
\text { feladatokat készít, így ők rendszere- } \\
\text { sen sikert érnek el. }\end{array}$ & $26 \%$ & $61 \%$ & $13 \%$ & $0 \%$ & $0 \%$ & 4,1 \\
\hline $\begin{array}{l}\text { Különböző tanulási stratégiákat } \\
\text { tanít, így a tanulás könnyebb és } \\
\text { hatékonyabb lesz. }\end{array}$ & $19 \%$ & $45 \%$ & $36 \%$ & $0 \%$ & $0 \%$ & 3,8 \\
\hline
\end{tabular}

2. táblázat: A tanulói önbizalom növelésére használt stratégiák gyakorisága $(\mathrm{n}=31)$

\subsection{A célorientáltság növelése}

A 3. táblázat a célorientáltság növelésére használt mikrostratégiák gyakoriságát mutatja be. A táblázatban megfigyelhető, hogy az adatközlők több mint egyharmada (11 fó, 36\%) mindig ösztönzi tanulóit arra, hogy legyenek rövid távú megvalósítható céljaik, és 
a válaszadók közel fele (13 fó, 42\%) gyakran alkalmazza ezt a mikrostraatégiát. A kutatásban részt vett nyelvtanárok szintén több mint egyharmada (11fö, 35\%) mindig segíti diákjait abban, hogy reálisan lássák nyelvtudásukat és fejlődésüket, és az adatközlők közel fele (13 fö, 42\%) gyakran követi ezt a példát. A táblázatban az is látható, hogy a válaszadók ritkábban térképezik fel tanulóik szükségleteit, céljait és érdeklődési körét, $s$ építik bele ezeket az órák tananyagába, csupán 3 fó (10\%) végzi ezt a tevékenységet mindig, de a megkérdezettek több mint fele (19 fó, 61\%) gyakran alkalmazza ezt a mikrostraatégiát. A legritkábban alkalmazott mikrostratégia - amelyet az adatközlők fele (15 fó, 48\%) soha nem végez - a falra kitett célok és azok eredményeinek rendszeres áttekintése az elért eredmények tükrében, néhányan (3 fö, 10\%) azonban gyakran élnek ezzel a lehetőséggel.

\begin{tabular}{|c|c|c|c|c|c|c|}
\hline stratégiák & 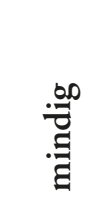 & 氙 & $\frac{\widetilde{J}}{\mathbb{\Xi}}$ & 跑 & 푱 & 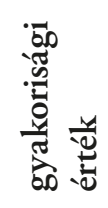 \\
\hline $\begin{array}{l}\text { Bátorítja a tanulóit, hogy legyenek } \\
\text { saját realista rövid-távú céljaik (pl. } \\
\text { tanuljanak meg } 5 \text { szót mindennap). }\end{array}$ & $35 \%$ & $42 \%$ & $20 \%$ & $3 \%$ & $0 \%$ & 4,1 \\
\hline $\begin{array}{l}\text { Segíti a tanulókat, hogy reálisan } \\
\text { lássák saját nyelvtudásukat és } \\
\text { fejlődésüket. }\end{array}$ & $35 \%$ & $42 \%$ & $23 \%$ & $0 \%$ & $0 \%$ & 4,1 \\
\hline $\begin{array}{l}\text { Megtudja tanulói szükségleteit, } \\
\text { céljait és érdeklődési körüket és } \\
\text { ezeket beépíti az órába, amennyire } \\
\text { csak lehet. }\end{array}$ & $10 \%$ & $61 \%$ & $26 \%$ & $3 \%$ & $0 \%$ & 3,8 \\
\hline $\begin{array}{l}\text { Kiteszi a falra az elérendő célokat } \\
\text { és rendszeresen áttekinti azokat } \\
\text { az elért eredmények tükrében. }\end{array}$ & $0 \%$ & $10 \%$ & $16 \%$ & $26 \%$ & $48 \%$ & 1,9 \\
\hline
\end{tabular}

3. táblázat: A célorientáltság növelésére használt stratégiák gyakorisága $(\mathrm{n}=31)$

\subsection{A tanulói teljesítmény elismerése}

A 4. táblázat a tanulói teljesítmény elismerésére használt mikrostratégiák gyakoriságát tartalmazza. A táblázatban látható, hogy a vizsgálatban részt vett nyelvtanárok nagy része (22 fö, 71\%) mindig értékeli tanulói erőfeszítéseit, eredményeit, és ezt ki is mutatja diákjainak, az adatközlők közel harmada (9 fö, 29\%) gyakran követi ezt a példát. Az is megfigyelhető a táblázatban, hogy a válaszadók közel fele (13 fö, 42\%) mindig arra bíztatja tanulóit, hogy tanuljanak szorgalmasabban, mert sikertelenségükért nem rossz 
képességük okolható, hanem a szorgalmuk hiánya. A kutatásban részt vett nyelvtanárok több mint egyharmada (11 fö, 36\%) gyakran alkalmazza ezt a mikrostraatégiát. Az adatközlők egyharmada (10 fö, 33\%) mindig úgy osztályoz, hogy az adott jegy nemcsak a tanulói teljesítményt tükrözi, de a tanulói erőfeszítést is, a válaszadók közel kétharmada (19 fö, 61\%) gyakran követi ezt a példát. A kutatásban résztvevők csupán negyede (8fo, 26\%) követi mindig figyelemmel a diákok teljesítményét és szentel időt a sikerek megünneplésére, a megkérdezett nyelvtanárok több mint egyharmada (12 fö, 39\%) azonban gyakran alkalmazza ezt a mikrostraatégiát.

\begin{tabular}{|c|c|c|c|c|c|c|}
\hline stratégiák & 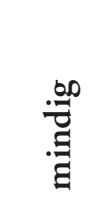 & 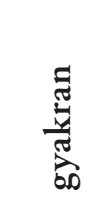 & 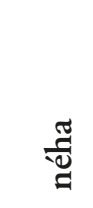 & 䒖 & $\frac{\pi}{0}$ & 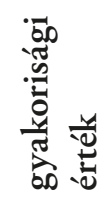 \\
\hline $\begin{array}{l}\text { Megmutatja a tanulóknak, hogy } \\
\text { erőfeszítéseiket és eredményeiket } \\
\text { elismeri. }\end{array}$ & $71 \%$ & $29 \%$ & $0 \%$ & $0 \%$ & $0 \%$ & 4,7 \\
\hline $\begin{array}{l}\text { Arra bíztatja a tanulóit, hogy } \\
\text { sikertelenségük oka nem a rossz } \\
\text { képességük miatt van, hanem nem } \\
\text { elegendő szorgalmuk miatt. }\end{array}$ & $42 \%$ & $36 \%$ & $19 \%$ & $3 \%$ & $0 \%$ & 4,2 \\
\hline $\begin{array}{l}\text { Az adott osztályzatok nem csak } \\
\text { a tanulói teljesítményt tükrözik, de } \\
\text { a tanulói erőfeszítést is. }\end{array}$ & $33 \%$ & $61 \%$ & $3 \%$ & $3 \%$ & $0 \%$ & 4,2 \\
\hline $\begin{array}{l}\text { Nyomon követi a tanulók telje- } \\
\text { sítményét és időt szán a sikerek } \\
\text { megünneplésére. }\end{array}$ & $26 \%$ & $39 \%$ & $32 \%$ & $3 \%$ & $0 \%$ & 3,9 \\
\hline
\end{tabular}

4. táblázat: A tanulói teljesítmény elismerésére használt stratégiák gyakorisága $(\mathrm{n}=31)$

Összehasonlítva a három makrostratégia gyakoriságát megfigyelhető, hogy összességében a tanulói önbizalom növelésére használt mikrostratégiákat alkalmazzák a kutatásban részt vevő nyelvtanárok a leggyakrabban. A tanulói teljesítmény elismerésére használt mikrostratégiákat ritkábban használják a válaszadók. A célorientáltság növelésére használt mikrostratégiákat pedig a legritkábban alkalmazzák a megkérdezettek. Összehasonlítva az egyes mikrostratégiákat megállapítható, hogy a vizsgálatban részt vettek leginkább a nyelvtanulói fejlődést veszik észre és pozitív visszajelzést adnak erről; elismerik diákjaik erőfeszítéseit és eredményeit; valamint világossá teszi tanulóik számára, hogy a nyelvtanulásban a legfontosabb a hatékony kommunikáció és nem a nyelvtani hibák miatti aggódás. 
A jelen kutatás eredményeit összehasonlítva a Dörnyei Zoltán és Csizér Kata által végzett vizsgálattal elmondható, hogy a tanulói önbizalom növelésére és a tanulói teljesítmény elismerésére alkalmazott mikrostratégiákat gyakrabban használják a jelen kutatás résztvevői, a célorientáltság növelése azonban hasonlóan ritkán alkalmazott makrostratégia. Ha a bemutatott vizsgálat eredményeit összehasonlítjuk a Hsing-Fu Cheng és Dörnyei Zoltán által folytatott kutatással, megállapítható, hogy a jelen vizsgálat is hasonló eredményeket mutatott a tanulói önbizalom és a tanulói teljesítmény elismerésére alkalmazott mikrostratégiák esetében, de a célorientáltság növelésére alkalmazott mikrostratégiákat a tajvani tanárok gyakrabban használják, mint a jelen vizsgálat magyar résztvevői.

\section{5. Összegzés}

A tanulmány első része a kutatás elméleti hátterét és a témához kapcsolódó vizsgálatok eredményeit mutatta be. A második részben az angol és német nyelvtanárok körében végzett empirikus kutatás eredményeit ismerhettük meg. Az eredmények rávilágítottak arra, hogy a vizsgálatban részt vett tanárokat erős belső motiváció jellemzi, és rendszeresen továbbképzéseken vesznek részt, fejlesztik tudásukat. A kutatásból azt is megtudtuk, hogy mely makro- és mikrostratégiákat alkalmaznak a leggyakrabban a kutatás adatközlői, és melyek azok, amelyekre nagyobb hangsúlyt érdemes fektetni a jövőben a nyelvtanulói motiváció erősítése érdekében.

\section{Irodalom}

Babbie, Earl 2001. A társadalomtudományi kutatás gyakorlata. Budapest: Balassi Kiadó.

Bárdos Jenő 2000. Az idegen nyelvek tanitásának elméleti alapjai és gyakorlata. Budapest: Nemzeti Tankönyvkiadó.

Cheng, Hsing-Fu - Dörnyei Zoltán 2007. The use of motivational strategies in language instruction: The case of EFL teaching in Taiwan. Innovation in Language Learning and Teaching 1: 153-174. https://doi.org/10.2167/illt048.0

Dörnyei Zoltán - Csizér Kata 1998. Ten commandments for motivating language learners: results of an empirical study. Language Teaching Research 2: 203-229. https:// doi.org/10.1191/136216898668159830

Dörnyei Zoltán 2001. Motivational strategies in the language classroom. Cambridge: Cambridge University Press. https://doi.org/10.1017/CBO9780511667343

Mackey, Alison - Gass, Susan 2005. Second language research: Methodology and design. London: Lawrence Erlbaum Associates Publishers. 